\title{
Is arterial switch operation possible with neonatology-focused intensive care unit modality
}

\author{
Neonatoloji odakı yoğun bakım modalitesi ile arteriyel switch ameliyatı yapılabilir mi?
}

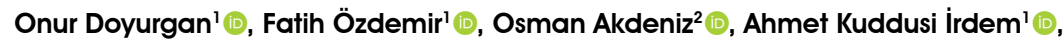

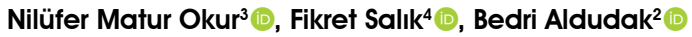 \\ 'Department of Pediatric Cardiovascular Surgery, Health Sciences University, Gazi Yaşargil Training and Research Hospital, Diyarbakır, Turkey \\ ${ }^{2}$ Department of Pediatric Cardiology, Health Sciences University, Gazi Yașargil Training and Research Hospital, Diyarbakır, Turkey \\ ${ }^{3}$ Department of Neonatology, Health Sciences University, Gazi Yaşargil Training and Research Hospital, Diyarbakır, Turkey \\ ${ }^{4}$ Department of Anesthesiology and Reanimation, Health Sciences University, Gazi Yaşargil Training and Research Hospital, Diyarbakır, Turkey
}

\begin{abstract}
Background: In this study, we aimed to examine the feasibility of arterial switch operation and its perioperative management with neonatology-focused intensive care modality in a region of Turkey where the birth rate and the number of asylum seekers who had to leave their country due to regional conflicts are high.

Methods: Between December 2017 and June 2020, a total of 57 patients (48 males, 9 females; median age: 12.2 days; range, 2 to 50 days) who were diagnosed with transposition of the great arteries in our clinic and underwent arterial switch operation were retrospectively analyzed. All patients were followed by the neonatologist in the neonatal intensive care unit during the preoperative and postoperative period.
\end{abstract}

Results: Thirty-eight (66.7\%) patients had intact ventricular septum, $16(28.1 \%)$ had ventricular septal defect, two (3.5\%) had coarctation of the aorta, and one $(1.7 \%)$ had Taussig-Bing anomaly. Coronary artery anomaly was present in $14(24.5 \%)$ patients. The most common complications in the intensive care unit were renal failure requiring peritoneal dialysis in seven $(12.3 \%)$ patients, supraventricular tachyarrhythmia in six $(10.5 \%)$ patients, and eight (14\%) patients left their chests open. The median length of stay in intensive care unit was 13.8 (range, 9 to 25) days and the median length of hospital stay was 24.5 (range, 16 to 47 ) days. The overall mortality rate for all patients was $12.3 \%(\mathrm{n}=7)$. The median follow-up was 8.2 months. A pulmonary valve peak Doppler gradient of $\geq 36 \mathrm{mmHg}$ was detected in five patients $(8.7 \%)$ who were followed, and these patients were monitored by providing medical treatment. None of the patients needed reoperation or reintervention.

Conclusion: We believe that arterial switch operation, one of the complex neonatal cardiac surgery, can be performed with an acceptable mortality and morbidity rate with the use of neonatology-focused intensive care modality, which is supported by pediatric cardiology and pediatric cardiac surgery.

Keywords: Arterial switch operation, COVID-19, intensive care, refugee, pandemic.

\section{$\ddot{o} Z$}

Amaç: Bu çalışmada, Türkiye'nin doğum oranı ve bölgesel çatışmalar nedeniyle ülkelerinden ayrılmak zorunda kalan sığınmacı sayısının yüksek olduğu bir bölgesinde, arteriyel switch ameliyatının ve neonatoloji odaklı yoğun bakım modalitesi ile perioperatif yönetiminin uygulanabilirliği incelendi.

Çalışma planı: Aralık 2017 - Haziran 2020 tarihleri arasında büyük arter transpozisyonu tanısı konan ve arteriyel switch ameliyatı yapılan toplam 57 hasta (48 erkek, 9 kadın; medyan yaş: 12.2 gün, dağılım, 2-50 gün) retrospektif olarak incelendi. Tüm hastalar ameliyat öncesi ve ameliyat sonrası dönemde yenidoğan yoğun bakım ünitesinde neonatoloji uzmanı tarafından izlendi.

Bulgular: Hastaların 38'inde (\%66.7) intakt ventriküler septum, 16'sında (\%28.1) ventriküler septal defekt, ikisinde (\%3.5) aort koarktasyonu ve birinde (\%1.7) Taussig-Bing anomalisi vardı. On dört hastada (\%24.5) koroner arter anomalisi mevcuttu. Yoğun bakım ünitesinde en sık görülen komplikasyonlar yedi hastada (\%12.3) periton diyalizi gerektiren böbrek yetmezliği, altı hastada (\%10.5) supraventriküler taşiaritmi idi ve sekiz hastada (\%14) göğüs açık olarak ameliyattan çıkıldı. Medyan yoğun bakım ünitesinde kalış süresi 13.8 gün (dağ 11 ım, 9-25) gün ve medyan hastanede kalış süresi 24.5 (dağ 11 ım, 16-47) gün idi. Tüm hastalar için genel mortalite oranı $\% 12.3$ $(\mathrm{n}=7)$ olarak bulundu. Medyan takip süresi 8.2 ay idi. Takip edilen hastaların beşinde (\%8.7) pulmoner kapak peak Doppler gradiyenti $\geq 36 \mathrm{mmHg}$ saptandı ve bu hastalar medikal tedavi verilerek izlendi. Hiçbir hastada yeniden ameliyat veya yeniden girişim gerekmedi.

Sonuç: Arteriyel switch ameliyatı gibi yenidoğanın kompleks kalp ameliyatları sonrası yoğun bakım takibinin, çocuk kardiyolojisi ve çocuk kalp cerrahisinin de desteklediği neonatoloji odaklı yoğun bakım modalitesi ile kabul edilebilir bir mortalite ve morbidite oranı ile yapılabileceği kanaatindeyiz.

Anahtar sözcükler: Arteriyel switch ameliyatı, COVID-19, yoğun bakım, mülteci, pandemi.

Received: June 15, 2020 Accepted: January 06, 2021 Published online: April 26, 2021

Correspondence: Onur Doyurgan, MD. SBÜ Gazi Yaşargil Eğitim ve Araştırma Hastanesi, Çocuk Kalp ve Damar Cerrahisi Anabilim Dalı, 21090 Bağlar, Diyarbakır, Türkiye. Tel: +90 537 - 4758109 e-mail: onurdoyurgan@gmail.com

Cite this article as:

Doyurgan O, Özdemir F, Akdeniz O, İrdem AK, Matur Okur N, Salık F, et al. Is arterial switch operation possible with neonatology-focused intensive care unit modality. Turk Gogus Kalp Dama 2021;29(2):136-142 
The transposition of the great arteries (TGA), the most common cyanotic congenital heart disease in newborns and infants, constitutes 5 to $7 \%$ of congenital heart defects. ${ }^{[1,2]}$ The current treatment method is the arterial switch operation (ASO), which provides anatomical correction, was first described in 1976 by Jatene et al. ${ }^{[3]}$ This operation also known as the Jatene procedure which is usually performed in the first month of the life. ${ }^{[4]}$ These patients, who need a surgical intervention in the neonatal period, require a precise follow-up and treatment regimen in the preand postoperative period, as well as sufficient surgery and intraoperative management.

In Turkey, pediatric cardiac intensive care management has been undertaken by pediatric cardiologists or anesthesiologists, without discriminating between newborn and infant, particularly in reference cardiac surgery centers. On the other hand, it may not always be possible to provide an independent pediatric cardiac intensive care unit (ICU) in newly established centers.

In the present study, we aimed to investigate the feasibility of ASO, one of the complex congenital heart surgeries of the neonatal period, and perioperative management with neonatology-focused intensive care modality.

\section{PATIENTS AND METHODS}

This single-center, retrospective study was conducted at Health Sciences University, Gazi Yaşargil Training and Research Hospital between December 2017 and June 2020. A total of 57 patients (48 males, 9 females; median age: 12.2 days; range, 2 to 50 days) who were diagnosed with the TGA in our clinic and underwent ASO were retrospectively analyzed using the hospital database. A written informed consent was obtained from each parent and/or legal guardian of the patient. The study protocol was approved by the Health Sciences University, Gazi Yaşargil Training and Research Hospital Ethics Committee (approval date/no: 15.5.2020/473). The study was conducted in accordance with the principles of the Declaration of Helsinki.

The body weight of the patients varied between 2,500-4,250 g (median: 3,250 g). A total of 38 patients $(66.7 \%)$ were diagnosed with TGA + intact ventricular septum (IVS), 16 patients $(28.1 \%)$ had TGA + ventricular septal defect (VSD), one patient (1.7\%) had Taussig-Bing anomaly, and two patients $(3.5 \%)$ had aortic coarctation accompanying the diagnosis. Coronary artery anomaly was identified in 14 patients (24.6\%), among which the most common coronary artery anomaly was the anomaly in which the right coronary artery arose from the circumflex artery. Five (8.7\%) patients had a single coronary ostium arising from sinus 2, two $(3.5 \%)$ patients had left coronary artery with intramural course, and one $(1.8 \%)$ patient had inverted right coronary and circumflex artery. All patients were diagnosed by echocardiography. Preoperative balloon atrial septostomy was performed in 24 patients $(42.1 \%)$ with insufficient intracardiac shunt and intact ventricular septum or restrictive atrial septum. Prostaglandin E1 infusion was administered to $76 \%$ of the patients before surgery (Table 1).

\section{Operative technique}

Cardiopulmonary bypass (CPB) was initiated with ascending aortic cannulation and bicaval venous cannulation in all patients under $28^{\circ} \mathrm{C}$ systemic hypothermia was applied. In the patients to whom antegrade selective cerebral perfusion was applied, cannulation was performed through the innominate artery. For myocardial protection, $20 \mathrm{~mL} / \mathrm{kg}$ antegrade single dose of cold Del Nido cardioplegia was used in the last 55 patients. In 21 patients $(36.8 \%)$ whose crossclamping time exceeded $90 \mathrm{~min}$, an additional $10 \mathrm{~mL} / \mathrm{kg}$ of cold blood cardioplegia was given every $20 \mathrm{~min}$. The right and left pulmonary artery were released up to the hilus branches. Patent ductus arteriosus was ligated and divided. After cross-clamping the ascending aorta, the aorta was transected near the sinotubular junction and the main pulmonary artery was transected at the proximal of the bifurcation. The coronary arteries were removed in the form of a large diameter button, taking care not to stretch or bend them. The released coronary arteries were anastomosed to their new locations using $8 / 0$ polypropylene sutures after forming openings in the form of hockey stick incision in the neoaorta. Following the LeCompte maneuver, neoaortic anastomosis was performed with $7 / 0$ polypropylene suture. A single semicircular autogenous pericardial patch was used for neopulmonary artery reconstruction and, then, the commissure left between the defects was fixed on the inner wall of this pericardium with a $7 / 0$ polypropylene suture (Figure 1). The diameter mismatch was eliminated by expanding with anterior longitudinal aortotomy in seven of nine patients $(15.7 \%)$ with a diameter mismatch between the aorta and pulmonary artery, and in two of them by performing triangular tissue resection and plication from the pulmonary artery wall. Ventricular septal defect was closed by standard techniques through right atrial approach. In a patient with subpulmonic VSD, the VSD was closed through the pulmonary artery. Aortic arch repair was performed in one patient with 
Table 1. Preoperative and operative data

\begin{tabular}{|c|c|c|c|c|c|}
\hline & $\mathrm{n}$ & $\%$ & Mean \pm SD & Median & Range \\
\hline Age at operation (days) & & & & 12.2 & $2-50$ \\
\hline \multicolumn{6}{|l|}{ Sex } \\
\hline Males & 48 & & & & \\
\hline Females & 9 & & & & \\
\hline Mean weight $(\mathrm{kg})$ & & & & 3.25 & 2.5-4.25 \\
\hline \multicolumn{6}{|l|}{ Diagnosis } \\
\hline TGA with IVS & 38 & 66.7 & & & \\
\hline TGA with VSD & 16 & 28.1 & & & \\
\hline Taussig-Bing & 1 & 1.7 & & & \\
\hline \multicolumn{6}{|l|}{ Associated malformations } \\
\hline TGA with aortic coarctation & 2 & 3.5 & & & \\
\hline \multicolumn{6}{|l|}{ Coronary artery pattern } \\
\hline Normal (1LAD, Cx; 2RCA) & 43 & 75.5 & & & \\
\hline Circumflex from RCA (1LAD; 2RCA, Cx) & 6 & 10.5 & & & \\
\hline Single RCA (2LAD, Cx, RCA) & 5 & 8.7 & & & \\
\hline Intramural LCA (2LAD, Cx, RCA) & 2 & 3.5 & & & \\
\hline Inverted RCA/Cx (1LAD, RCA; 2Cx) & 1 & 1.8 & & & \\
\hline Diameter mismatch between the aorta and pulmonary artery & 9 & 15.7 & & & \\
\hline Patients who previously had balloon atrial septostomy & 24 & 42.1 & & & \\
\hline Mean CPB time (min) & & & & 183.8 & $136-275$ \\
\hline Mean AXC time (min) & & & & 116.2 & $82-189$ \\
\hline Aristotle Complexity score & & & $12.9 \pm 2.2$ & & \\
\hline
\end{tabular}

SD: Standard deviation; TGA: Transposition of the great arteries; IVS: Intact ventricular septum; VSD: Ventricular septal defect; LAD: Left anterior descending; Cx: Circumflex artery; RCA: Right coronary artery; LCA: Left coronary artery; CPB: Cardiopulmonary bypass; AXC: Aortic cross-clamp.

aortic coarctation using an autogenous pericardial patch treated with glutaraldehyde and in one patient by extended arch aortoplasty. In the patients where balloon atrial septostomy was previously performed or the patients with atrial septal defect, the defect was primarily closed; however, a small diameter patent foramen ovale was left open. Modified ultrafiltration procedure was performed on all of the last 55 (96.4\%) patients after leaving the CPB. The sternum of eight patients (14\%) whose sternum was left open was closed on the second postoperative day (range, 1 to 5 days). Operative data are presented in Table 1.

\section{Postoperative care and follow-up}

The patients were postoperatively followed by a team lead by a neonatologist, with an allocated nurse team, in a section specially reserved for cardiac surgery patients in the neonatal ICU, suitable for full monitoring. In the postoperative early period, pediatric cardiology and cardiac surgery team also provided close management support.

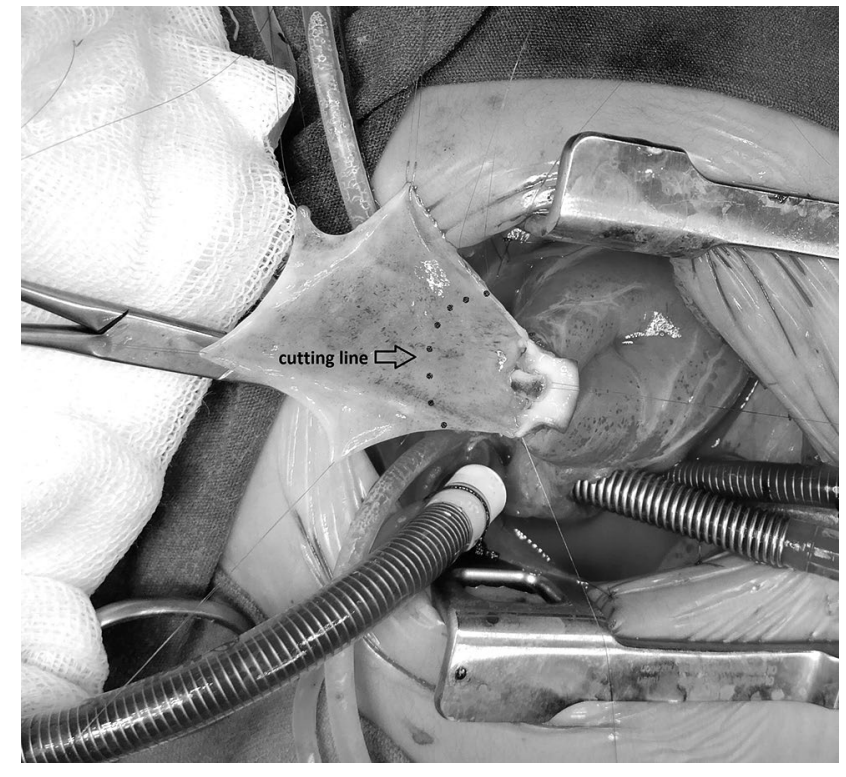

Figure 1. Pulmonary artery reconstruction using a semi-circular single autogenous pericardial patch. 
Table 2. Postoperative data

\begin{tabular}{lcccc}
\hline & $\mathrm{n}$ & $\%$ & Median & Range \\
\hline Mean intensive care unit stay (days) & & & 13.8 & $9-25$ \\
Duration of mechanical ventilation (days) & & & 4 & $1-21$ \\
Duration of noninvasive respiratory support (days) & & & 11 & $6-25$ \\
Time to achieve full enteral feeding & & & 8 & $5-28$ \\
Complications* & & & & \\
$\quad$ Delayed chest closure & 7 & 14 & & \\
Acute renal failure and peritoneal dialysis & 6 & 10.3 & & \\
Arrhythmias & 5 & 8.7 & & \\
Left ventricular dysfunction & 5 & 8.7 & & \\
Ventricular fibrillation and cardiac arrest & 3 & 5.2 & & \\
Bleeding & 3 & 5.2 & & \\
Pneumonia & 2 & 3.5 & & \\
Necrotising enterocolitis & 2 & 3.5 & & \\
Coagulopathy & 2 & 3.5 & & \\
Sepsis (with proven infection) & 1 & 1.8 & & \\
Seizures & 1 & 1.8 & & \\
Intracranial hemorrhage & 1 & 1.8 & & \\
Diaphragm paresis & 7 & 12.3 & & \\
Early mortality (postoperative 1-30 days) & & & 8.2 & \\
Mean follow-up time (months) & &
\end{tabular}

In postoperative period, the patients were given fentanyl/remifentanil and midazolam infusion for sedation and analgesia for at least $24 \mathrm{~h}$. In the patients who were hemodynamically unstable or whose sternum was left open, the sedation period was extended. All patients were monitored by electrocardiography (ECG), oxygen saturation, invasive arterial pressure, central venous pressure, and cranial near-infrared spectroscopy during their stay in ICU. For inotropic support, epinephrine (0.05 to $0.4 \mu \mathrm{g} / \mathrm{kg} / \mathrm{min})$ and milrinone ( 0.3 to $0.7 \mu \mathrm{g} / \mathrm{kg} / \mathrm{min}$ ) were among the firstly preferred choices. In addition to these inotropes, noradrenaline and dopamine infusion was added to patients with low diastolic blood pressure arteries. The left ventricular functions were followed using daily echocardiography during the ICU period. Complications observed during ICU follow-up were carefully recorded (Table 2).

\section{Statistical analysis}

Statistical analysis was performed using the IBM SPSS for Windows version 23.0 software (IBM Corp., Armonk, NY, USA). Continuous variables were presented in mean \pm standard deviation $(\mathrm{SD})$, median (min-max), while categorical variables were expressed in number and percentage. The Fisher's exact test was used for evaluating the categorical variables. The Mann-Whitney U test was used to analyze abnormally distributed variables. A $p$ value of $<0.05$ was considered statistically significant.

\section{RESULTS}

The mean Aristotle complexity score of the patients was $12.9 \pm 2.2$. The mean Aristotle scores of the patients who died were found to be statistically significantly higher compared to the surviving patients (15.1 \pm 2.26 vs. $12.6 \pm 2.05$, respectively; $\mathrm{p}=0.01)$. There were no statistically significant differences between the mean Aristotle scores of the refugees bearing foreign nationality and Turkish nationals $(13.2 \pm 2.4 v s .12 .7 \pm 2.1$, respectively; $\mathrm{p}>0.05)$. Four $(23.5 \%)$ of the 17 foreign newborns and three (7.5\%) of the 40 local newborns died. This tendency of higher mortality in foreign nationals was not statistically significant $(p=0.09)$. The hospital mortality was $12.3 \%(n=7)$. Five of them died intraoperatively, as they could not be weaned from $\mathrm{CPB}$, and two died within the first postoperative week due to sepsis. The causes of death in the patients lost intraoperatively were insufficient myocardial protection in two patients, poor coronary transfer in two patients, and unknown cause (probably coronary thrombosis) in one patient. One of these two patients in whom we had 
coronary transfer problems had an intramural course anomaly of the left coronary artery and the other had a kinking in the right coronary artery problem after anastomosis. Although coronary anastomoses were removed and rebuilt, these patients died in operating room. For the patients who were discharged, the median duration of hospitalization in the ICU was 13.8 (range, 9 to 25 ) days and the median hospital stay was 24.5 (range, 16 to 47) days, the median mechanical ventilation time was 4 (range, 1 to 21) days, the median duration of non-invasive respiratory support was 11 (range, 6 to 25) days, and the median time to achieve full enteral feeding was 8 (range, 5 to 28) days. Necrotising enterocolitis (NEC) was seen in two patients (3.5\%). All of these patients were fully recovered with discontinuation of enteral feeding and medical treatment. Transient peritoneal dialysis was performed in seven (12.3\%) patients with medical treatment-resistant metabolic acidosis and oliguria or edema. Hemodynamically significant supraventricular tachyarrhythmia was observed in six (10.5\%) patients during their stay in the postoperative ICU. Supraventricular tachyarrhythmia was primarily eliminated by giving intravenous adenosine to these patients. Then, amiodarone infusion continued to be given as maintenance therapy. Two patients with Klebsiella pneumoniae growth in the postoperative blood culture died due to Gram-negative bacterial sepsis and multiple organ failure, despite appropriate antibiotic therapy. Complications encountered in the ICU are shown in Table 2. Our patients were followed regularly by the pediatric cardiologist at three and six months using echocardiographic examination. In none of the patients, hemodynamically significant VSD was detected and no re-intervention due to pulmonary stenosis or another reason was needed. In 21 of the patients $(36.8 \%)$, the mean highest flow velocity in Doppler echocardiography in the main pulmonary artery or its branches was found to be $2.4 \pm 0.6 \mathrm{~m} / \mathrm{s}$ (measured gradient $24 \pm 12 \mathrm{mmHg}$ ). In five of the patients $(8.7 \%)$, the pulmonary valve peak Doppler gradient was $\geq 36 \mathrm{mmHg}$. However, medical treatment was given to these clinically asymptomatic patients; no intervention was made to relieve the pulmonary valve. The median follow-up time of our patients after discharge was 8.2 (range, 1 to 26) months, and their effort capacity is still New York Heart Association (NYHA) Class 1.

\section{DISCUSSION}

Due to the regional conflicts and civil wars, many refugees migrated to neighboring countries. According to the data from the Immigration Authority of Turkey, there is over 4,000,000 asylum seekers living in our country under "temporary protection status" and they benefit from healthcare services. The Southeastern Anatolia Region is one of the regions in our country with the highest birth rate and refugee population. Therefore, a significant portion $(45 \%)$ of the patient burden of our newly established center, contrary to expectations, consists of complex patients in the neonatal age group. The TGA is one of the most important complex pathologies of this age group requiring emergency/early surgery. The novel coronavirus-2019 (COVID-19) pandemic at the end of 2019 has imposed an enormous burden on healthcare systems and due to human mobility restrictions, patient referrals to reference centers became difficult and the number of referrals decreased dramatically. ${ }^{[5]}$ It has become necessary to build our intensive care modality as soon as possible. In patients requiring speeding up the process, it was decided to establish a separate compartment inside the existing neonatal ICU where patients undergoing congenital heart surgery can be followed.

Of course, there are significant differences between the notion of neonatology and pediatric cardiac intensive care. These two approaches differ from each other in various aspects such as fluid regimen, invasive pressure follow-ups, patient intervention, and blood gas follow-up. A surgical approach naturally involves not innocent, but necessary techniques following cardiac surgery such as replacement of large amounts of blood and blood products, initiating peritoneal dialysis to draw fluid, if necessary, and even following an open sternum patient. On the other hand, the neonatology department prefers to be cautious about replacement of blood products and fluids, frequent blood tests, and even capillary blood gas tests. Due to such differences, most of the reference centers in Turkey prefer to follow neonates in pediatric cardiac intensive care along with infants and other pediatric patients. However, this brings about some disadvantages, despite its justifications. For instance, a neonatologist has inevitably more expertise in subjects such as enteral feeding and monitoring of the gastrointestinal tract or non-invasive mechanical ventilation support of the newborn.

We aimed to develop a multidisciplinary perspective which allows to emphasize the strengths of each department with the neonatology-focused intensive care modality we created. Inspired by the guidelines involved in the organization of pediatric cardiovascular intensive care, inside the neonatal ICU, a four-bed separate unit was designed with sufficient physical and technical conditions allowing full monitoring and 
emergency surgery, when necessary. ${ }^{[6]}$ Close patient follow-up required in the pre- and postoperative period was provided by establishing a separate team with a sufficient number of newborn nurses who underwent pediatric cardiology training. We attempted to do that as pediatric cardiology and cardiac surgery were at the forefront in hemodynamic and surgical follow-up, particularly in the early postoperative period, while neonatology encompassed fluid regimen, nutrition, and mechanical ventilation strategies.

Enteral feeding was started and achieved to full enteral feeding as soon as possible, depending on gastrointestinal system tolerance. While the incidence of NEC following congenital heart disease surgery in the literature is 3.3 to $11 \%,{ }^{[7]}$ the rate of NEC was $3.5 \%(n=2)$ in our series. These patients were treated with discontinuation of enteral feeding and medical treatment thanks to early diagnosis and treatment and were discharged fully recovered. We believe that the notion of neonatology plays a major role in overcoming NEC, which is one of the scariest postoperative complications in the neonatal period, without mortality and morbidity.

Sepsis is one of the most threatening and mortal complications of the postoperative period after neonatal cardiac surgeries. In the literature, the frequency of sepsis is over $6 \%$ and has been reported to increase associated with the complexity of surgery. ${ }^{[8]}$ The rate of sepsis with proven infection in our series is $3.5 \%$, which is less than mentioned in the literature. In our opinion, this can be associated with the contribution of the notion of neonatology. Differences in the antibiotic regimen, early start of enteral feeding, closed incubator use, more frequent and effective application of non-invasive mechanical ventilation methods may explain the relatively low incidence of sepsis.

In the literature, the median length of stay of patients in the ICU and hospital in an advanced medical center, where ASOs are performed, is reported to be 8 days and 15 days, respectively. ${ }^{[9]}$ However, the length of the stay of postoperative patients in ICU in the first few years after arterial switch surgery in another center was reported to be longer and the length of stay in ICU decreased over time, as the experience of the center increased. ${ }^{[10]}$ Since our center is a newly established center, we have been more cautious about discharging our patients from ICU and the hospital. From this point of view, the relatively prolonged stay in ICU is compatible with the literature.
An arterial switch series of a reference center in Turkey reveals a mortality rate of $6.4 \% .^{[1]}$ It is reported by experienced centers in the world that early mortality in ASOs has been reduced to below $5 \%$. Risk factors for early mortality are reported to be body weight less than $2.5 \mathrm{~kg}$, resection for left ventricular outflow obstruction, concomitant aortic arch obstruction, prolonged CPB time. ${ }^{[12,13]}$ Although our mortality seems to be relatively high, it should be kept in mind that these data encompass a wide range of data, including learning curve period of a newly established center. The first two arterial switch patients were emergency and non-referrable patients that had to be taken into operation before the implementation of the neonatal perfusion strategy and planning. Both patients died in operating room and the cause of death was thought to be insufficient myocardial protection and myocardial insufficiency due to myocardial edema. In all 55 subsequent patients, myocardial protection was provided by Del Nido cardioplegia, thus, the traumatizing and time-consuming effect of recurrent cardioplegia was prevented. In our clinic, ASO has been performed successfully with applications such as modified ultrafiltration, high-dose steroid administration, and restrictive fluid regimen. The first death occurred on the $20^{\text {th }}$ operation after the new perioperative strategy was implemented.

A significant part of the patients was foreign nationals and receiving referrals from neighboring provinces without a prenatal diagnosis, and an increased number of our patients were in poor preoperative condition. This may explain the tendency of high mortality in the foreign nationals, compared to that of the local newborns. The scores of the patients who died were found to be higher compared to the surviving patients. The mean Aristotle complexity score, which predicts the operative risk factor, was $12.9 \pm 2.2$. Considering these factors, it would be fair to conclude that our case series exhibited an acceptable rate of mortality.

Nonetheless, our study has some limitations. Small sample size and retrospective design of the study were the main limitations. In addition, the study was carried out based on a single-center. Therefore, further largescale, multi-center, prospective studies are required to confirm these findings.

In conclusion, the idea of creating a separate pediatric cardiac intensive care, which is frequently preferred by reference centers, may not always be possible in newly established centers, particularly in unexpected times of social crisis such as refugee 
influx and pandemic. Thus, we aimed to organize this neonatology-focused intensive care modality in line with our needs and capabilities. Thus, it has contributed to the reduction of medical risks and costs with air ambulance in patient transportation processes. We believe that this intensive care model can be preferred for neonatal cardiac intensive care units, particularly in the new regional centers to be established.

\section{Declaration of conflicting interests}

The authors declared no conflicts of interest with respect to the authorship and/or publication of this article.

\section{Funding}

The authors received no financial support for the research and/or authorship of this article.

\section{REFERENCES}

1. Khairy P, Clair M, Fernandes SM, Blume ED, Powell AJ, Newburger JW, et al. Cardiovascular outcomes after the arterial switch operation for D-transposition of the great arteries. Circulation 2013;127:331-9.

2. Moons P, Gewillig M, Sluysmans T, Verhaaren H, Viart P, Massin M, et al. Long term outcome up to 30 years after the Mustard or Senning operation: a nationwide multicentre study in Belgium. Heart 2004;90:307-13.

3. Jatene AD, Fontes VF, Paulista PP, Souza LC, Neger F, Galantier M, et al. Anatomic correction of transposition of the great vessels. J Thorac Cardiovasc Surg 1976;72:364-70.

4. Yildız O, Ozturk E, Onan S, Tanıdır C, Ergul Y, Guzeltas A, et al. Late primary arterial switch operation in patients with transposition of great arteries and intact ventricular septum. Turk Gogus Kalp Dama 2016;24:415-21.

5. Korun O, Yurdakök O, Arslan A, Çiçek M, Selçuk A, Kılıç Y, et al. The impact of COVID-19 pandemic on congenital heart surgery practice: An alarming change in demographics. J Card Surg 2020;35:2908-12.

6. Section on Cardiology and Cardiac Surgery; American Academy of Pediatrics. Guidelines for pediatric cardiovascular centers. Pediatrics 2002;109:544-9.

7. Lau PE, Cruz SM, Ocampo EC, Nuthakki S, Style CC, Lee TC, et al. Necrotizing enterocolitis in patients with congenital heart disease: A single center experience. J Pediatr Surg 2018;53:914-917.

8. Barker GM, O'Brien SM, Welke KF, Jacobs ML, Jacobs JP, Benjamin DK Jr, et al. Major infection after pediatric cardiac surgery: a risk estimation model. Ann Thorac Surg 2010;89:843-50.

9. Wheeler DS, Dent CL, Manning PB, Nelson DP. Factors prolonging length of stay in the cardiac intensive care unit following the arterial switch operation. Cardiol Young 2008; 18:41-50.

10. García Hernández JA, Montero Valladares C, Martínez López AI, Romero Parreño A, Grueso Montero J, GilFournier Carazo M, et al. Risk factors associated with arterial switch operation for transposition of the great arteries. Rev Esp Cardiol 2005;58:815-21.

11. Dedemoğlu M, Coşkun G, Özdemir F, Yurdakök O, Korun O, Çiçek M, et al. Modified Closed Coronary Transfer is a Good Alternative to the Trap-Door Method During Arterial Switch Operation: a Retrospective Propensity-Matched Comparison. Braz J Cardiovasc Surg 2020;35:329-38.

12. Santens B, Van De Bruaene A, De Meester P, Gewillig M, Troost E, Claus P, et al. Outcome of arterial switch operation for transposition of the great arteries. A 35-year follow-up study. Int J Cardiol 2020316:94-100.

13. Fricke TA, d'Udekem Y, Richardson M, Thuys C, Dronavalli M, Ramsay JM, et al. Outcomes of the arterial switch operation for transposition of the great arteries: 25 years of experience. Ann Thorac Surg 2012;94:139-45. 